UDK/UDC: 004.414.23:532.535

Prejeto/Received: 17.09 .2020

Izvirni znanstveni članek - Original scientific paper

Sprejeto/Accepted: 04.11.2020

\title{
TWO-DIMENSIONAL HYDRAULIC MODELLING OF SUBMERGED RIVER TRAINING STRUCTURES
}

\section{DVODIMENZIONALNO HIDRAVLIČNO MODELIRANJE POTOPLJENIH REČNIH UREJEVALNIH OBJEKTOV}

\author{
Davor Kvočka ${ }^{1}$ \\ ${ }^{1}$ Faculty of Civil and Geodetic Engineering, University of Ljubljana, Jamova cesta 2, 1000 Ljubljana, \\ Slovenia
}

\begin{abstract}
River training structures, such as dikes and chevrons, are commonly used for improving riparian navigation conditions. These structures are usually submerged under most flows and are aligned at variable angles to the main river flow direction. In this study, two different approaches for two-dimensional hydraulic modelling of submerged dikes and chevrons in MIKE 21 Flow Model FM have been analysed: (i) by representing the geometry of the structures explicitly in the bathymetry of the river channel (i.e. bathymetry approach), and (ii) by utilising the "dike" sub-grid module, where the flow past a structure is calculated by employing an empirical discharge relationship (i.e. dike module approach). The model results have been compared to theoretical and empirical studies, as well as to field observations and measurements. The obtained results indicate that the bathymetry approach is the more appropriate method for simulating predominantly submerged river training structures. However, these types of models should be used only for general assessment of potential river engineering solutions. For more detailed analysis of solution options, more complex models are recommended, e.g. three-dimensional hydrodynamic models.
\end{abstract}

Keywords: hydraulic modelling, river training structures, river engineering, chevron dikes, submerged weir flow

\section{Izvleček}

Rečni urejevalni objekti, kot so jezbice in podkvasti usmerjevalniki toka, se pogosto uporabljajo za izboljšanje plovnih pogojev na rekah. Ti objekti so večino časa potopljeni in so lahko postavljeni pod različnimi koti glede na glavno smer rečnega toka. V tej študiji smo analizirali dva različna pristopa za dvodimenzionalno hidravlično modeliranje potopljenih jezbic in podkvastih usmerjevalnikov toka $\mathrm{v}$ programu MIKE 21 Flow Model FM: (i) z eksplicitnim prikazom geometrije objektov v batimetriji rečnega kanala (tj. batimetrični pristop) in (ii) z uporabo »jezbičnega « podmrežnega modula, kjer se pretok mimo konstrukcije izračuna $\mathrm{z}$ uporabo empirično določenega koeficienta pretoka (tj. pristop z uporabo jezbičnega

\footnotetext{
${ }^{1}$ Stik / Correspondence: davor.kvocka@fgg.uni-lj.si

(C) Kvočka D.: This is an open-access article distributed under the terms of the Creative Commons Attribution - NonCommercial ShareAlike 4.0 Licence.

(C) Kvočka D.: Vsebina tega članka se sme uporabljati v skladu s pogoji licence Creative Commons Priznanje avtorstva Nekomercialno - Deljenje pod enakimi pogoji 4.0.
}

https://doi.org/10.15292/acta.hydro.2020.06 
modula). Modelne rezultate smo primerjali s teoretičnimi in empiričnimi študijami kakor tudi s terenskimi opazovanji in meritvami. Dobljeni rezultati kažejo, da je batimetrični pristop ustreznejša metoda za simulacijo pretežno potopljenih rečnih urejevalnih objektov. Vseeno je priporočljivo tovrstne modele uporabljati le za splošno ovrednotenje potencialnih inženirskih rešitev. Za podrobnejšo analizo potencialne tehnične rešitve je priporočljiva uporaba kompleksnejših modelov, kot so tridimenzionalni hidrodinamični modeli.

Ključne besede: hidravlično modeliranje, rečni urejevalni objekti, rečno inženirstvo, podkvasti usmerjevalniki toka, tok preko potopljenega preliva

\section{Introduction}

River training structures are manmade structures designed and constructed in a river reach to modify the hydraulic flow and sediment response of a river (US Army Corps of Engineers, 2012). These types of structure are commonly used for improving navigation conditions on low-land rivers, such as the Waal, Elbe, Danube, Rhine and Thames in Europe, the Mississippi in the USA, the White Nile and Nile Rivers in Sudan and Egypt, and the Me Kong River in Vietnam (Le et al., 2018). Even though river training structures have been designed to facilitate river navigation, the novel type of these structures (e.g. chevrons and longitudinal training dams) can also enhance the heterogeneity of the physical aquatic habitat, increase invertebrate abundance and diversity, provide a habitat for a variety of fish species, and facilitate the ecological rehabilitation of regulated rivers (Remo et al., 2013; Collas et al., 2018).

River training structures are usually submerged under most flows and are aligned at variable angles to the main river flow direction. These types of structures mostly operate in one of two flow modes: (i) "dry crest" mode, where water levels upstream and downstream from the structure are below the crest level, or (ii) "submerged nonmodular" mode, where water levels upstream and downstream from the structure are above the crest level with sub-critical flows over the crest. The difference in water level across these structures is usually not large, as the structures occupy only a portion of the river channel, allowing flow to pass around them and equalise the water levels. Modular weir flow (i.e. critical depth on the crest) only occurs for a very limited range of river flow when the depth of flow over the structure is very shallow. For the dry crest mode, no flow passes over the structure. For the submerged non-modular flow mode, the flow component perpendicular to the structure can be estimated through standard weir flow equations by applying an appropriate discharge reduction coefficient, while the velocity component parallel to the weir is largely unaffected by the structure (Wols et al., 2006).

The majority of studies that have considered river training structures have focused on the constructed structures' river training performance, environmental impact, or flood risk impact (Theiling, 1995; Davinroy, 1996; Maddock, 1999; Dyhouse and Brauer, 2010; Pinter et al., 2012; Remo et al., 2013; Sobotka and Phelps, 2017; Luo and Criss, 2018). On the other hand, only a handful of studies have investigated the hydrodynamic performance of these structures using laboratory experiments or numerical modelling (Papanicolaou and Elhakeem, 2006; Gessler et al., 2010; Huthoff et al., 2013; Zuijderwijk et al., 2013; Singh and Sharma, 2014). Therefore, there is lack of information on how to properly characterize these types of structures in two-dimensional (2D) hydraulic models, such as the MIKE 21 Flow Model FM, which are often used as the main support tool in river engineering projects.

There are generally two different approaches that can be employed for 2D modelling the flow over and around submerged river trading structures. The first approach is to represent the training structures explicitly in the $2 \mathrm{D}$ model by modifying the model bathymetry. The flow over the submerged structures is thus calculated through the shallow water equations based on the $2 \mathrm{D}$ depth-integrated velocities. The flow that passes over the submerged structure will lead to the contraction in 
the depth of flow on the structure crest, with this contraction potentially persisting further downstream from the structure. The downstream contraction in the depth of flow would not be fully accounted for in the depth-integrated velocities and momentum flux in the model, which may result in the underestimation of the energy loss (or pressure difference) across the structure.

The alternative approach to including the effect of the river training structures is utilising the sub-grid modules that are incorporated in the 2D modelling suites, such as the dike sub-grid module within MIKE 21 Flow Model FM. In the dike sub-grid module approach, the flow past a structure is calculated by employing an empirical discharge relationship. The dike sub-grid module calculates the flow past the structure for each individual mesh element along the entire length of the structure line and is based on the local mesh element water levels upstream and downstream from the specified dike line. The river training structures are often (i) placed in the middle of the river (e.g. chevrons), or (ii) connected to the bank, but extend only part way into the river and are not generally perpendicular to the flow (e.g. spur dikes and wing dams). Since the key assumption behind the dike sub-grid modelling technique is that the structure is perpendicular to the flow direction, modelling the submerged structures by using the sub-grid modelling elements may lead to unrealistic flow distributions around the structures.

There are therefore limitations in representing submerged structures in 2D hydraulic models either by explicitly modifying the river bathymetry or utilising the sub-grid modules. Thus, this paper investigates the appropriateness of the two aforementioned approaches for 2D hydraulic modelling of submerged river training structures. MIKE 21 Flow Model FM has been employed to model the proposed dikes and chevrons at the two separate locations on the Romanian-Bulgarian common sector of the Danube River. The model results have been compared to the most relevant theoretical and empirical studies, as well as to the actual field observations and measurements.

\section{Flow over a submerged weir - empirical and theoretical relations}

A weir is a hydraulic structure that can be used to measure flow, control the river discharge, decrease the water slope in the channel, and distribute water between canals for irrigation. In general, weirs can be divided in two groups (Chadwick et al., 2013): (i) sharp-crested (thin plate) weirs, which are generally rectangular, V-shaped, or trapezoidal, and (ii) broad-crested (long-based) weirs, which are generally rectangular, round-nosed, or have a triangular profile (e.g. crump weirs). In this study, the focus will be on broad-crested weirs, since the modelled structures proposed can be classified (from hydraulic point of view) as long-based structures.

For a plain weir placed normal to the flow direction, the discharge relation for the free-flow conditions can be written as (Bos, 1989):

$q_{0}=\frac{2}{3} C_{d f} \sqrt{\frac{2}{3} g H_{0}^{\frac{3}{2}}}$

where $q_{0}\left(\mathrm{~m}^{3} / \mathrm{s} / \mathrm{m}\right)$ is the specific discharge (discharge per unit length), $C_{d f}$ is the discharge coefficient for free-flow conditions, $g\left(\mathrm{~m} / \mathrm{s}^{2}\right)$ is the gravitational acceleration, and $H_{0}(\mathrm{~m})$ is the upstream energy head.

When a weir is submerged, the calculated flow rate (i.e. discharge relation) will overestimate the actual flow rate. Therefore, a correction for submergence must be included in the calculation to allow for the reduction of flow over the weir. The general relation for the submerged specific discharge over a weir can be written as (Ali and Uijttewaal, 2014):

$q=C_{d f} C_{d} \frac{2}{3} \sqrt{\frac{2}{3}} g H_{0}^{\frac{3}{2}}=C \frac{2}{3} \sqrt{\frac{2}{3}} g H_{0}^{\frac{3}{2}}$

Considerable amount of research has focused on investigating the submergence effects on the hydraulic performance of sharp-crested weirs (Villemonte, 1947; Ramamurthy et al., 1987; Wu and Rajaratnam, 1996; Borghei et al., 1999; Johnson, 2000; Göğüş et al., 2006; Bagheri and Heidarpour, 2010; Kumar et al., 2011). However, a 
relatively small number of investigations have been conducted on submerged flows over broadcrested weirs. These investigations include the studies conducted by Villemonte (1947), Fritz and Hager (1998), Azimi et al. (2014), and Ali and Uijttewaal (2014).

In his experimental study, Villemonte (1947) applied the principle of superposition to the submerged linear weir flow problem, with the assumption being that the flow over a submerged linear weir is equal to the difference between the free-flow discharge associated with upstream and downstream driving heads. Based on his experiments, Villemonte (1947) developed a relatively accurate and widely used discharge reduction factor, which describes the submergence effects on the hydraulic performance of sharpcrested linear weirs (Table 1).

Fritz and Hager (1998) conducted an experimental study, which investigated the flow characteristics of submerged embankment weirs with upstream and downstream slopes of $1 \mathrm{~V}: 2 \mathrm{H}$. The effect of crest length, approach flow, and tailwater submergence on embankment performance were considered, with particular attention being given to the velocity field in the tailwater. It was established that submerged embankment flows involve four flow regimes (i.e. A-jump, plunging jet, surface wave, surface jet), with the type of the flow regime depending on the submergence ratio and relative crest length. Fritz and Hager (1998) proposed an empirical discharge reduction factor for submerged flow conditions, which is based on the submergence ratio and relative crest length (Table 1).

Azimi et al. (2014) conducted an experimental study, which focused on submerged flow over rectangular weirs of finite crest length.
Characteristics length scales, such as wave length and amplitude at the modularity limit, and the location of the first trough downstream from the weir, were measured to generalise surface profiles at different flow discharges. They proposed an empirically based discharge reduction factor for weirs of finite crest length, which employs two exponents with different values for several classes of finite crest length weirs with either squareedged or rounded crest (Table 1).

Ali and Uijttewaal (2014) conducted an experimental study, which focused on determining the form drag due to vegetated, oblique, weir-like obstacles. Laboratory experiments have been undertaken to measure the energy head losses for a range of subcritical flow conditions, varying discharges, and downstream water levels. The energy head loss caused by the submerged weirlike obstacle has been modelled using an expansion loss-form drag model. The theoretical solution (i.e. drag model) for flow over a weir is considered by calculating the energy and momentum balance over the structure: energy is conserved on the upstream side of the weir, while momentum is conserved on its downstream side. The drag model has been derived from the onedimensional energy and momentum conservation equations, and accounts for the energy loss associated with a deceleration of the flow downstream from a sudden expansion (Table 1).

Table 1 outlines the theoretical and empirical discharge reduction formulae for submerged weir flows proposed by Villemonte (1947), Fritz and Hager (1998), Azimi et al. (2014), and Ali and Uijttewaal (2014). These discharge reduction relations have been used to assess the performance of different modelling approaches considered for representing rigid structures in MIKE 21 Flow Model FM. 
Table 1: The empirical and theoretical discharge reduction formulae for submerged weir flows.

Preglednica 1: Empirične in teoretične formule za določitev redukcijskega koeficienta pri toku preko potopljenega preliva.

\begin{tabular}{|c|c|c|}
\hline Study & Discharge reduction coefficient formula & $\begin{array}{c}\text { Empirical } \\
\text { coefficients used }\end{array}$ \\
\hline Villemonte (1947) & $C_{d}=\left(1-\left(\frac{H_{2}}{H_{0}}\right)^{P}\right)^{0.385}$ & $\mathrm{P}=1.5$ \\
\hline Fritz and Hager (1998) & $C_{d}=\left(1-\frac{\left(\frac{H_{2}}{H_{0}}-y_{L}\right)}{\left(1-y_{L}\right)}\right)^{\frac{1}{n}}$ & $\begin{array}{c}\text { Max limit: } \\
\mathrm{y}_{\mathrm{L}}=0.85, \mathrm{n}=7 \\
\quad \text { Min limit: } \\
\mathrm{y}_{\mathrm{L}}=0.35, \mathrm{n}=4\end{array}$ \\
\hline Azimi et al. (2014) & $C_{d}=\left(1-\left(\frac{H_{2}}{H_{0}}\right)^{m}\right)^{n}$ & $\begin{array}{l}\mathrm{m}=10 \\
\mathrm{n}=0.95\end{array}$ \\
\hline Ali and Uijttewaal (2014) & $\begin{array}{c}d_{0}^{*}-\left(d_{1}^{*}+\Delta^{*}+\alpha_{1} \frac{1}{2 d_{1}^{* 2}}\right) d_{0}^{* 2}+\frac{1}{2} \alpha_{0}=0 \\
d_{1}^{* 3}+2 \Delta^{*} d_{1}^{* 2}+\left(\Delta^{* 2}-d_{2}^{* 2}-\beta_{2} \frac{2}{d_{2}^{*}}\right) d_{1}^{*}+2 \beta_{1}=0 \\
C_{d}=\frac{3 q}{2 \cdot \sqrt{\frac{2}{3} g} H_{0}^{\frac{3}{2}}}\end{array}$ & I \\
\hline
\end{tabular}

$C_{d}$ - discharge reduction coefficient, $H_{0}$ - upstream energy head; $H_{2}$ - downstream energy head; $H_{2} / H_{0}$ - submergence ratio; $p, n$, and $m$ - empirical coefficients; $y_{L}$ - modular limit; * indicates length scales made dimensionless using the critical depth above the weir crest; $d_{0}$ - water depth upstream from the weir; $d_{1}$ - water depth at the weir crest; $d_{2}-$ water depth downstream from the weir; $\Delta$ - weir height; $\alpha_{0}$ and $\alpha_{1}$ - dimensionless kinetic energy correction coefficients, and $\beta_{1}$ and $\beta_{2}$ - dimensionless momentum correction coefficients; $q$ - submerged specific discharge; $g-$ gravitational acceleration

\section{Modelling approach and methodology}

\subsection{Definitions}

Two different modelling approaches have been considered for representation of rigid structures in MIKE 21 Flow Model FM. In the first approach, the structures' geometry is represented explicitly in the bathymetry of the river channel. This approach will be referred to as the bathymetry approach. In the second approach, the effect of hydraulic structures is represented by utilising the dike subgrid module within MIKE 21 Flow Model FM. This approach will be referred to as the dike module approach.

In MIKE 21 Flow Model FM, the standard weir formula used in the dike sub-grid module is reduced according to the original Villemonte (1947) empirical relation, and is implemented as (DHI, 2017):
$Q=W \cdot C \cdot H_{0}^{k}\left[1-\left(\frac{H_{2}}{H_{0}}\right)^{k}\right]^{0.385}$

where $Q\left(\mathrm{~m}^{3} / \mathrm{s}\right)$ is the discharge over the structure, $W(\mathrm{~m})$ is the structure width, $C$ is the discharge coefficient for free-flow conditions, $H_{0}(\mathrm{~m})$ is the upstream energy head, $H_{2}(\mathrm{~m})$ is the downstream energy head, $H_{2} / H_{0}$ is the submergence level, and $k$ is the weir exponential coefficient, which is set to 1.5 and cannot be altered.

\subsection{Study area}

The in-channel structures considered in this study were developed within the FAST Danube project (www.fastdanube.eu). The project's main objective is to develop and implement technical solutions, which will ensure the required navigation conditions on the Romanian-Bulgarian common sector of the Danube, allowing for safe river transport throughout the year. Two different types of river training structures were considered for this 
paper: (i) chevrons near Dunavci in Bulgaria, and (ii) dikes (groynes) at the port of Corabia in Romania. The chevron modelling results were used for comparison with the field measurements, while the dike modelling results used for comparison with the empirical and theoretical discharge reduction formulae for submerged weir flows.

(a)

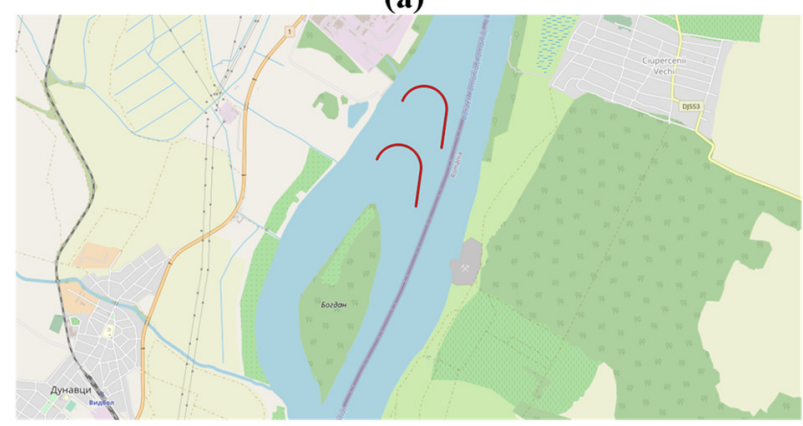

(b)

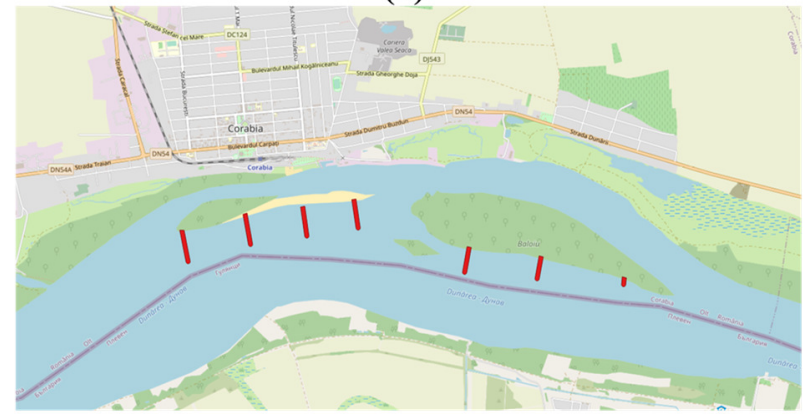

Figure 1: Chevrons near Dunavci, Bulgaria (a) and dikes at Corabia, Romania (b).

Slika 1: Podkvasti usmerjevalniki toka pri Dunavcih, Bolgarija (a), in jezbice pri Corabii, Romunija (b).

\subsection{D model schematisation}

\subsubsection{Representation of structures}

The crest level for the structures was set at $1 \mathrm{~m}$ above the local ENR (Etiage Navigable et de Régularisation) water level at the location of the proposed structure. This reflects the current European best practice, which is being developed within projects such as the Witzelsdorf Pilot Project (Glas et al., 2018), River Waal groyne lowering (van Vuren et al., 2015), and Pilot Project Bad Deutsch Altenburg (Liedermann et al., 2018). In this approach, the structures are submerged during higher flows to minimise unwanted negative impacts on the local environment and wildlife.
In the bathymetry approach, the structures were represented explicitly in the model by modifying the bathymetry through GIS software. The modelled structures were represented as squareedged, broad-crested weirs (i.e. rectangular crosssection), which leads to the crest width being as wide as the structure's base. This should help in reducing the underestimation of the energy loss across the structure due to the contraction in the depth of flow. As mentioned, the flow over the submerged structures is calculated through the shallow water equations based on the $2 \mathrm{D}$ depthintegrated velocities, which leads to the contraction in the depth of the flow on the structure crest. As the downstream contraction in the depth of flow is generally not fully accounted for in the depthintegrated velocities and momentum flux in the model, this may result in the underestimation of the energy loss (or pressure difference) across the structure. However, for submerged broad-crested structures, these losses are less significant than for sharp-crested structures, where the change of flow depth is much more abrupt (Huthoff et al., 2013). In the dike module approach, the structures were represented by specifying a dike line within MIKE 21 Flow Model FM. The dike line was traced along the middle of the crest of the considered structures in GIS software and was later converted to a data format used by MIKE 21 Flow Model FM.

\subsubsection{Model mesh configuration}

The 2D MIKE 21 FM model is based on a flexible mesh system. The model domain is represented by a network of triangular elements that form a connected mesh. The mesh is automatically generated by the software and the model resolution is controlled by specifying the maximum planform area that any individual element can occupy within the mesh. The mesh resolution can be varied in different parts of the model domain. As the mesh cell size is reduced, the number of elements in the model and the computation time for model simulations both increase.

For the dike module approach, no additional refinement of the basic model mesh was needed, as the dike lines are defined with polylines that are created using GIS software. For the bathymetry 
approach, polygons were created during the mesh generation process in order to outline each structure. Since the polygons were specified within the limit of each structure, the mesh cells generated were limited to the area of the polygon. This means that during the interpolation process (i.e. assigning of the bathymetry elevation data to the model mesh), the cells within the polygon were assigned only the bathymetry elevations representing the crest (or top level) of a structure. In this way, the structures preserved their originally defined shape and initially prescribed elevation when they were incorporated into the model mesh.

Furthermore, such an approach also enables having the optimal mesh resolution for the entire model domain, since the sizes of the cells within the polygons are automatically adapted to the polygon extent. Therefore, it was not necessary to specify higher-resolution mesh around the proposed structures, which significantly contributed to reducing the overall simulation times. An example of a local mesh refinement used to define the river training structures within the bathymetry approach is shown in Figure 2.

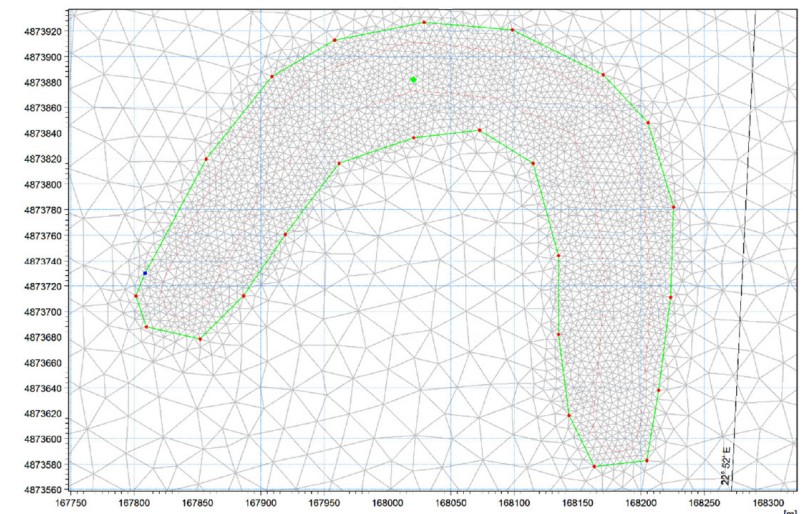

Figure 2: An example of a local mesh refinement in MIKE 21 Flow Model FM, where the green line indicates the extent of the local mesh refinement.

Slika 2: Primer lokalne zgostitve računske mreže v MIKE 21 Flow Model FM, kjer zelena črta označuje območje lokalne zgostitve računske mreže.

\section{Results}

\subsection{Comparison between empirical and theoretical formulae and model results}

\subsubsection{The dike module approach model results}

Figure 3 shows a comparison between the dike module approach model results and the considered empirical and theoretical discharge reduction formulae for submerged weir flows. It can be seen from Figure 3 that the dike module approach results agree relatively well with the Villemonte (1947) empirical relation, which is as expected since the dike module is based on the same empirical relation. However, the results also indicate that the dike module approach overestimates energy losses at higher flows (10000 - $12000 \mathrm{~m}^{3} / \mathrm{s}$ ), which is probably due to Villemonte's formula being developed primarily for submergence ratios smaller than 0.9 .

Figure 3 shows that the dike module approach significantly overestimated actual energy losses at the structures as compared to the empirical relation proposed by Fritz and Hager (1998). In contrast to the Villemonte (1947) formula, the Fritz and Hager (1998) empirical relation was developed for submerged embankment weirs. Therefore, these results are as expected, since the dike module formula is based on an empirical relation developed primarily for sharp-crested weirs. A relatively good agreement between empirical relation and the model results can be observed for lower flows (i.e. $5000-8000 \mathrm{~m}^{3} / \mathrm{s}$ ). The minimum limit line corresponds to a very narrow-crested weir. This makes it more similar to the sharpcrested weir, and thus to the empirical formula used in the dike module, which leads to better agreement between the formula and model results.

It can be also seen in Figure 3 that there is a generally good agreement between the empirical relation proposed by Azimi et al. (2014) and the model results of the dike module approach. The relation proposed by Azimi et al. (2014) is similar to the empirical formula used in the dike module, with the main difference being that it was developed for long-crested rectangular submerged weirs. The energy loss for such structures is less than for sharp-crested weirs, which introduce the most abrupt changes in the flow. 
Finally, Figure 3 also shows that there is a poor agreement between the drag model shown by Ali and Uijttewaal (2014) and the model results. The dimensionless weir height $\Delta^{*}$ is defined as the ratio between the weir height and the critical depth above the weir crest. The average value of $\Delta^{*}$ for this set of model results is 2.2 , which suggests that the dike module approach significantly overestimated the energy losses at the structures. As mentioned, the dike module formula is based on an empirical relation developed primarily for sharp-crested weirs, while the drag model proposed by Ali and Uijttewaal (2014) was developed specifically for submerged, trapezoidalsection, broad-crested weirs. Therefore, the empirical formula within the dike module approach would need to be re-parameterized in order to better simulate the submerged flow conditions.
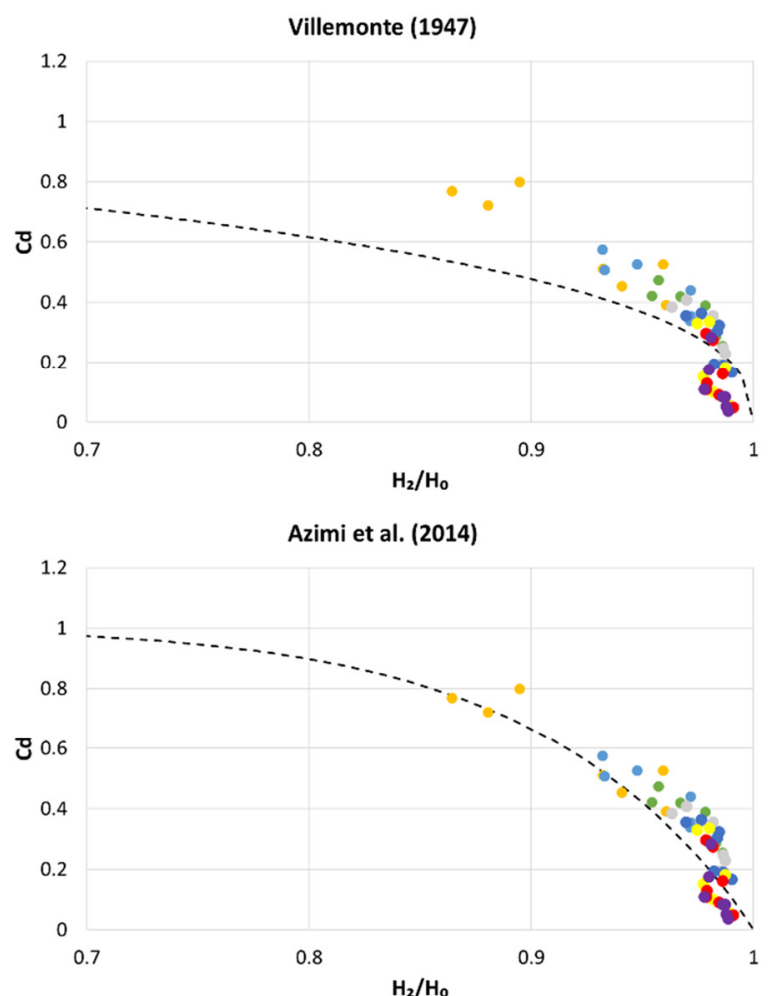

- $Q=5000 \mathrm{~m} 3 / \mathrm{s} \cdot Q=6000 \mathrm{~m} 3 / \mathrm{s} \bullet Q=7000 \mathrm{~m} 3 / \mathrm{s} \bullet Q=8000 \mathrm{~m} 3 / \mathrm{s}$

- $Q=9000 \mathrm{~m} 3 / \mathrm{s} \quad Q=10000 \mathrm{~m} 3 / \mathrm{s} \bullet Q=11000 \mathrm{~m} 3 / \mathrm{s} \bullet Q=12000 \mathrm{~m} 3 / \mathrm{s}$

Figure 3: The comparison between the empirical and theoretical formulae, and the dike module approach model results.

Slika 3: Primerjava med empiričnimi in teoretičnimi formulami in modelnimi rezultati za pristop z uporabo jezbičnega modula.

Compared to empirical and theoretical relations that are not based on some form of the Villemonte (1947) formula, the dike module approach appears to overestimate the energy losses at the structures. As structures get more and more submerged, the dike module approach estimates less and less flow over the structures (i.e. the value of $\mathrm{C}_{\mathrm{d}}$ gets smaller and smaller). Based on published research, the most effective way to improve the dike module's performance would be to increase the value of the empirical coefficient $\mathrm{k}$ (see Equation (3)) in line with the experimental findings for submerged trapezoidal weirs, e.g. $\mathrm{k}$ values in the range of 1525. However, the empirical coefficient k cannot be changed in the dike module. Only the free-flow discharge coefficient $\mathrm{C}$ can be varied. Therefore, simulations were performed with the discharge coefficient $\mathrm{C}$ increased by $100 \%$ (i.e. from 1.838 to 3.676).
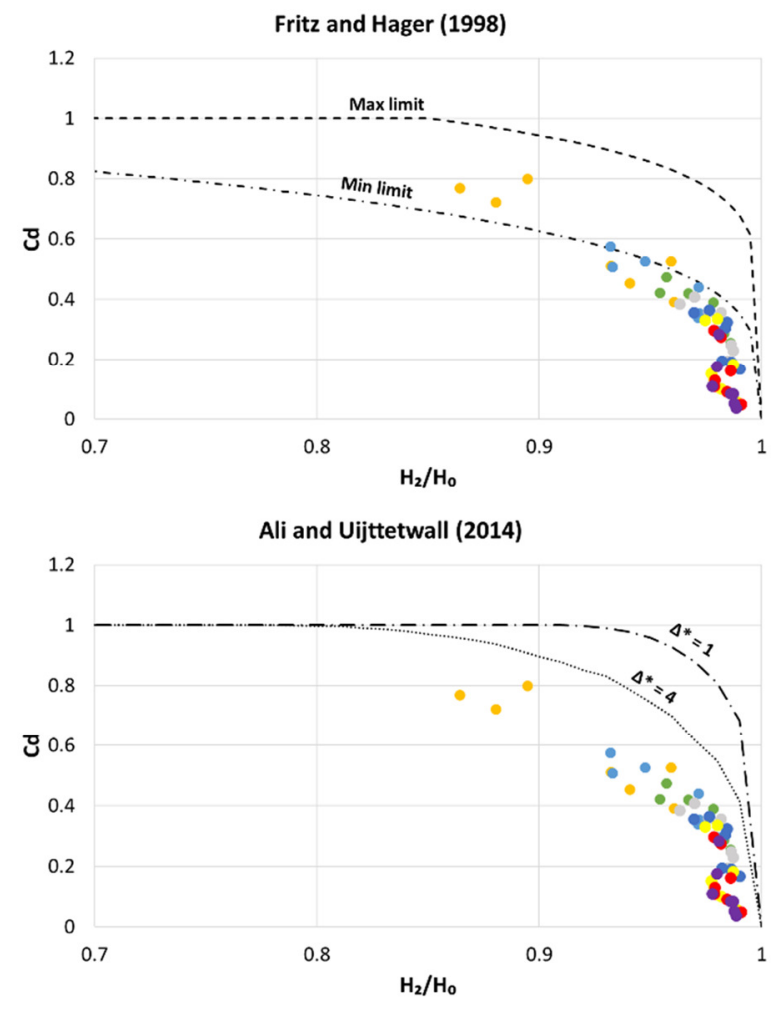
Figure 4 shows the comparison between the dike module approach, with higher results for the discharge coefficient model, and the considered empirical and theoretical discharge reduction formulae for submerged weir flows. It can be seen from Figure 4 that the increase in the value of the discharge coefficient generally did not lead to an improved agreement between the model results and the empirical and theoretical formulae. Even though more flow could pass over the structures, the model results still suggest that the dike module approach generally still overestimated the energy losses.
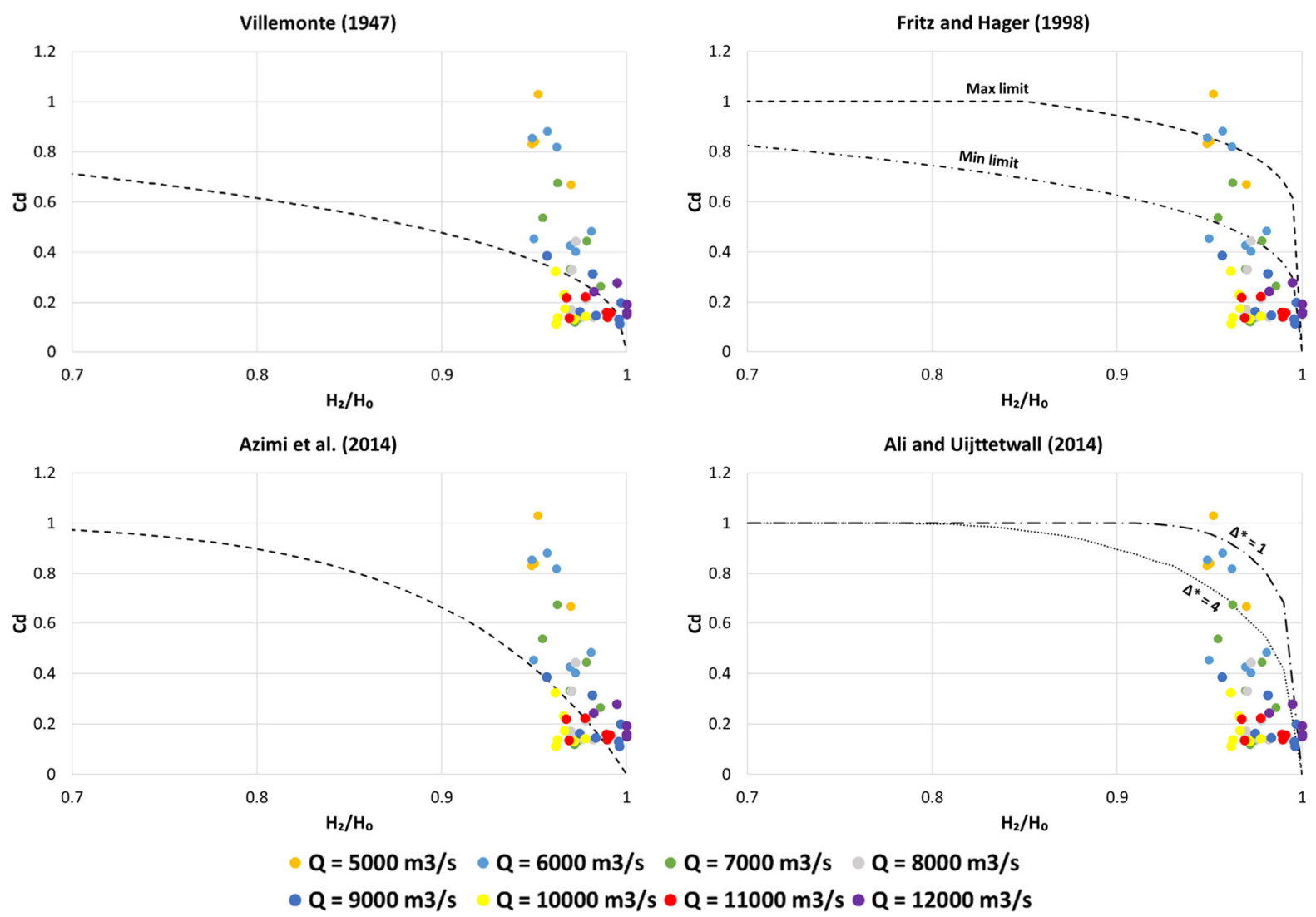

Figure 4: The comparison between the empirical and theoretical formulae and the dike module approach with higher discharge coefficient model results.

Slika 4: Primerjava med empiričnimi in teoretičnimi formulami in modelnimi rezultati za pristop z uporabo jezbičnega modula s povečanim koeficientom pretoka.

\subsubsection{The bathymetry approach model results}

Figure 5 shows a comparison between the results of the bathymetry approach model and the considered empirical and theoretical discharge reduction formulae for submerged weir flows. Model results were obtained at three locations for each of the considered dikes: 10m upstream from the upstream-edge of the structures, at the middle of the crests of the structures, and $10 \mathrm{~m}$ downstream from the downstream-edge of the structures. The extracted model results (i.e. water levels, water depths, velocities) were used to calculate the discharge reduction coefficient $C_{d}$ in Equation (2). For submerged flow conditions, the discharge coefficient for free-flow conditions $C_{d f}$ can be set to 1 (Ali and Uijttewaal, 2014).

When compared to the empirical relation proposed by Villemonte (1947), it appears that the bathymetry approach significantly underestimated the energy losses at the structures. However, these results are as expected, since the Villemonte's formula was developed primarily for sharp-crested 
weirs, which introduce a much more abrupt change in flow condition and energy loss.

It can be seen in Figure 5 that there is a good agreement between the Fritz and Hager (1998) empirical formula and the bathymetry approach model results. The model results particularly agree well with the maximum limit line, which was proposed for weirs with long crests. As mentioned, the modelled structures were represented as square-edged, broad-crested weirs (i.e. rectangular cross-section), with the crest width being as wide as the base of the structure (i.e. $40 \mathrm{~m}$ ). Therefore, the bathymetry model approach with a "stretchedcrest" principle appears to result in similar energy losses as experiments for submerged trapezoidal section structures.

Figure 5 shows that the bathymetry approach significantly underestimates the energy losses at
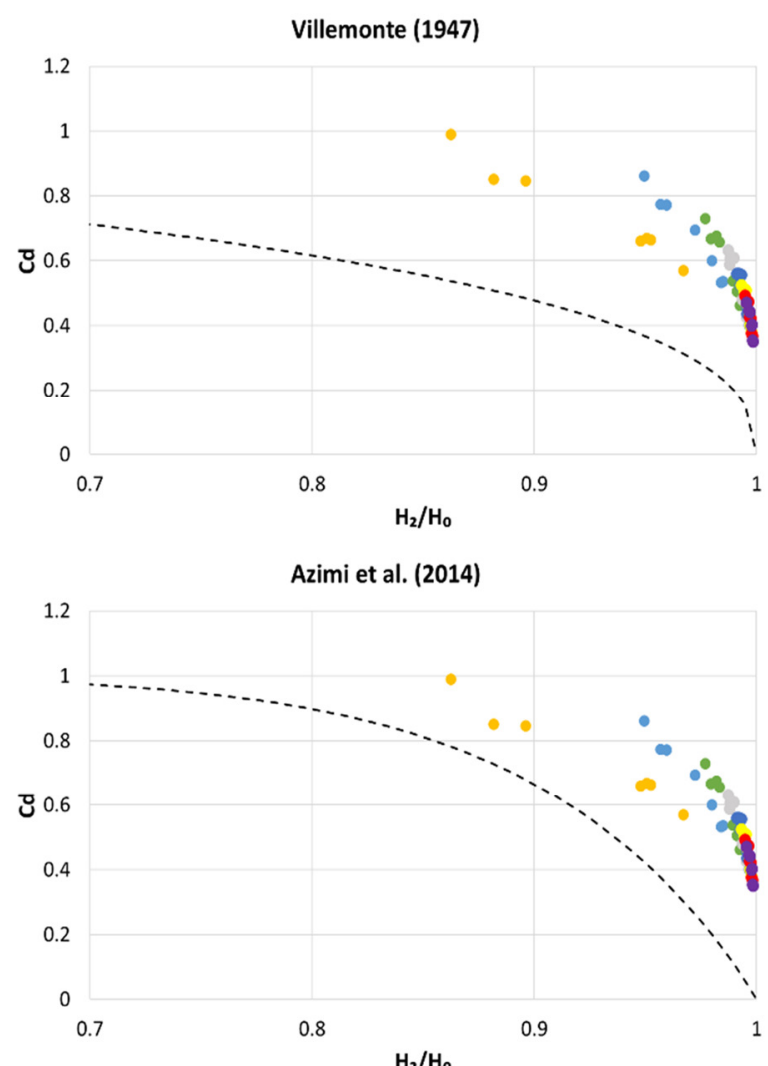

$\mathrm{H}_{2} / \mathrm{H}_{\mathrm{O}}$ the structures when model results are compared to the empirical formula proposed by Azimi et al. (2014). However, these results are as expected, since the Azimi et al. (2014) empirical relation is basically a variation of Villemonte's empirical formula, derived for square-edged weirs.

Finally, it can be also seen in Figure 5 that there is a relatively good agreement between the drag model produced by Ali and Uijttewaal (2014) and the bathymetry approach model results. The dimensionless weir height $\Delta^{*}$ is defined as the ratio between the weir height and the critical depth above the weir crest. The average value of $\Delta^{*}$ for this set of results is 2.2 , which suggests that the bathymetry approach slightly underestimates the energy losses at the structures.
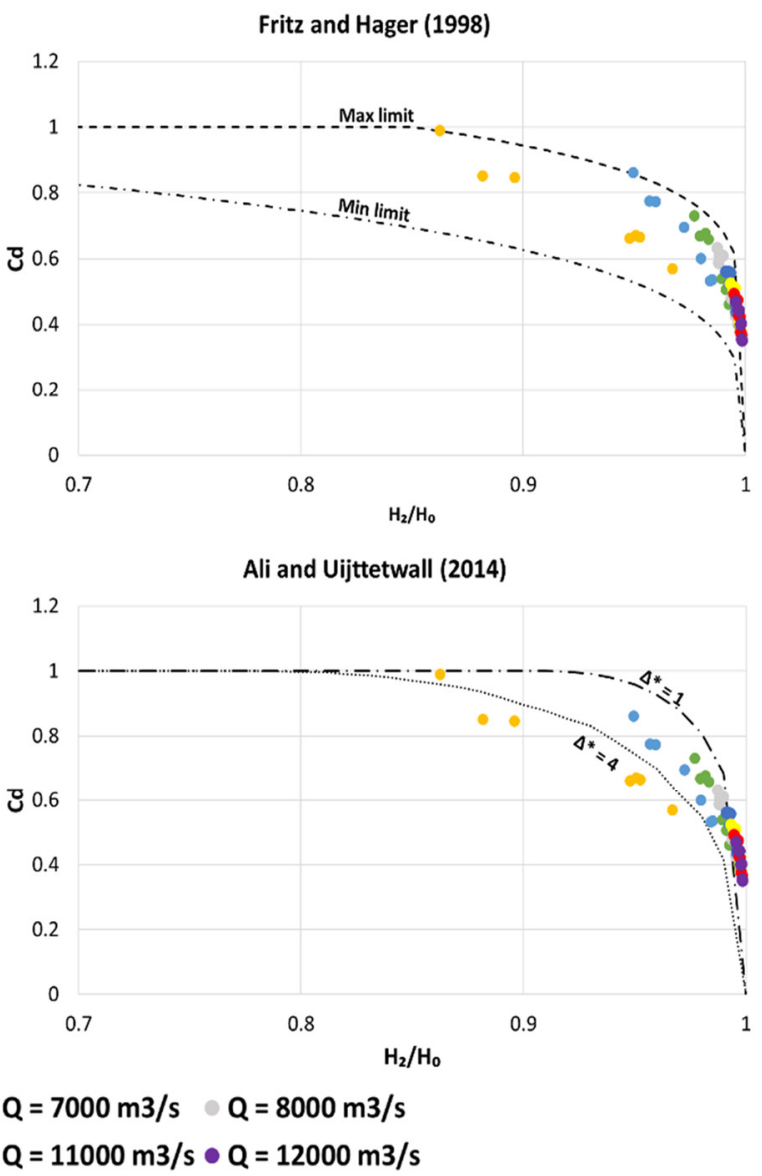

Figure 5: The comparison between the empirical and theoretical formulae, and the bathymetry approach model results.

Slika 5: Primerjava med empiričnimi in teoretičnimi formulami in modelnimi rezultati za batimetrični pristop. 
The energy loss at the structures using the bathymetry approach can be adjusted by varying the bed roughness at the structure. In order to assess the effectiveness of this approach, the model simulations have been repeated using a higher value of Manning's coefficient (i.e. 0.05) on the crests of the structures, which corresponds to the roughness of a typical chevron or groyne building material (e.g. riprap rock). An increase in the crest roughness should further increase the dissipation of the energy at the crest of the structure and thus to better model performance.

Figure 6 shows a comparison between the bathymetry approach with increased crest roughness model results and the considered empirical and theoretical discharge reduction
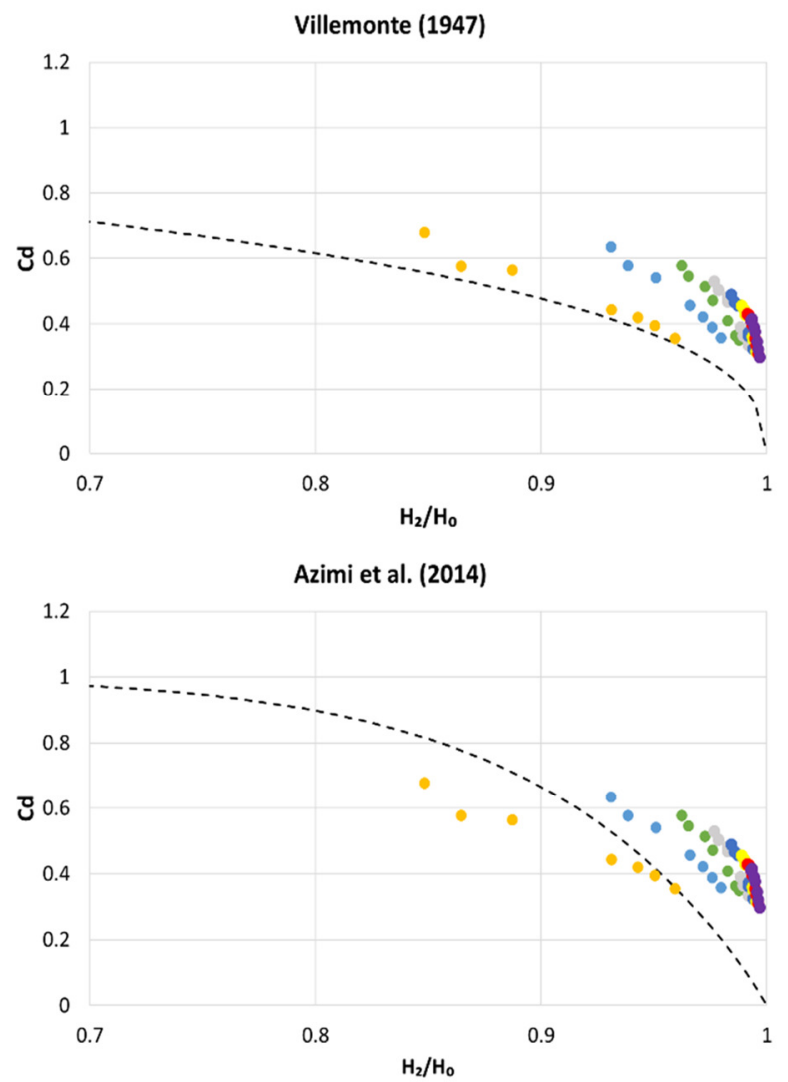

$$
\begin{aligned}
& \text { Q } Q=5000 \mathrm{m3} / \mathrm{s} \quad \bullet=6000 \mathrm{~m} 3 / \mathrm{s} \\
& \text { - } Q=9000 \mathrm{m3} / \mathrm{s} \quad \mathrm{Q}=10000 \mathrm{m3} / \mathrm{s} \bullet \mathrm{Q}=11000 \mathrm{m3} / \mathrm{s} \bullet \mathrm{Q}=12000 \mathrm{m3} / \mathrm{s}
\end{aligned}
$$
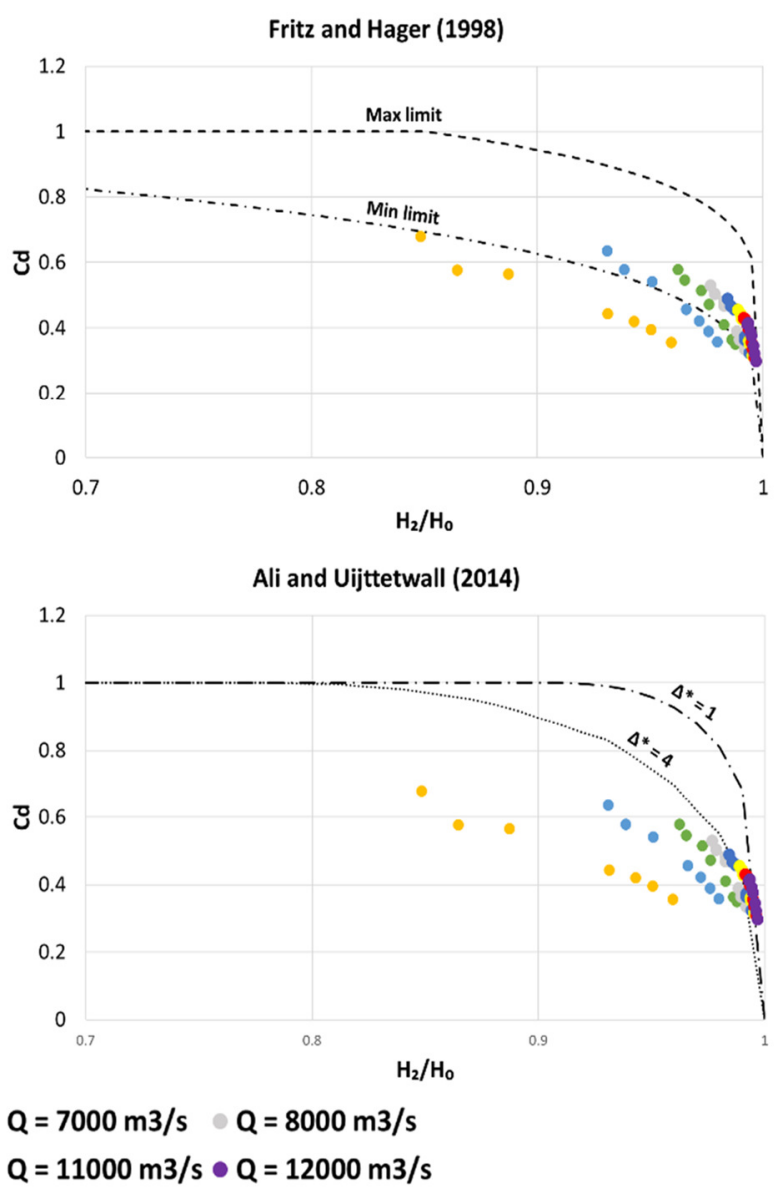

Figure 6: The comparison between the empirical and theoretical formulae and the bathymetry approach with increased crest roughness model results.

Slika 6: Primerjava med empiričnimi in teoretičnimi formulami in modelnimi rezultati za batimetrični pristop s povečano hrapavostjo krone preliva. 
Figure 7 shows flow around a chevron at St. Louis Harbour for different river stages. It can be seen in Figure 7 that the chevron's effect on the surrounding flow field diminishes with higher water levels. Furthermore, Figure 7 also shows that there is no visible flow split present once the chevron is fully submerged, i.e. water can pass over a submerged chevron with limited obstructions. This can be further seen in Figure 8, which shows the ADCP velocity measurements around one of the chevrons at St. Louis Harbour. This specific set of measurements was conducted at flow of $15300 \mathrm{~m}^{3} / \mathrm{s}$, with the structure being fully submerged at this flow.

It can be seen in Figure 8 that the flow passes above the submerged chevron, i.e. there is a limited flow split, as well as a change in the velocity magnitudes and directions. Velocities are slightly lower inside the chevrons, but this is expected. As mentioned, chevrons are overtopped during high water periods, which leads to the creation of larger scour holes within them. These scour holes then form deep pools with slow moving water inside the chevrons. Figure 8 also shows that there is generally no change in the flow direction on the structure crest when the flow passes over a submerged chevron.

It should be noted that both Figure 7 and Figure 8 are meant to be purely informative, i.e. to primarily show that, when the chevron is fully submerged, the flow above the submerged chevron can pass without any obstructions and that there is no split of the flow at the structure. All conclusions are based on a qualitative analysis, which means that they should be regarded only as a strong indication of what is happening around a submerged chevron.
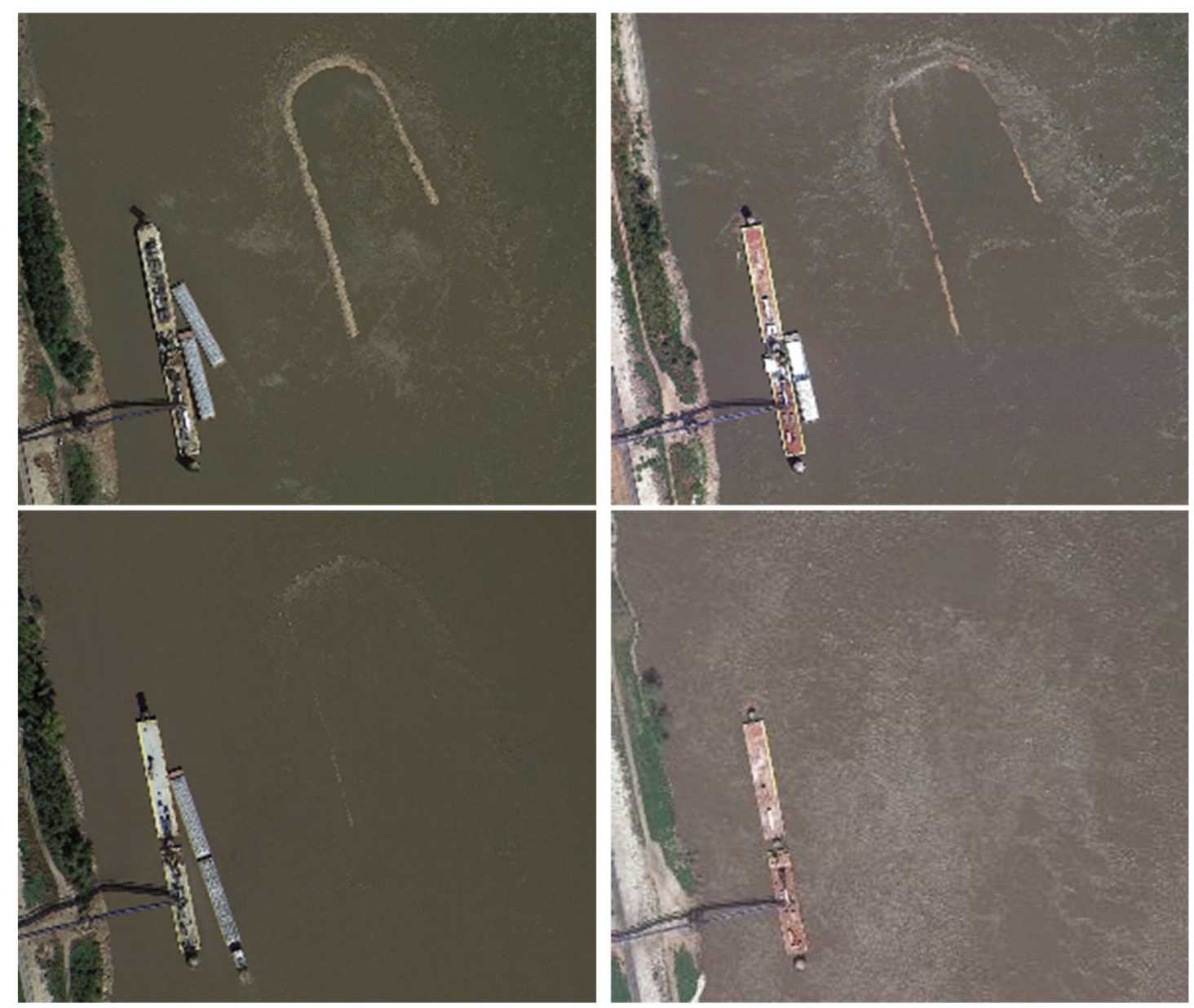

Figure 7: Flow around a chevron at St. Louis Harbor for different river stages (Google Earth).

Slika 7: Tok okoli podkvastega usmerjevalnika toka pri pristanišču St. Louis Harbor pri različnih vodostajih (Google Earth). 


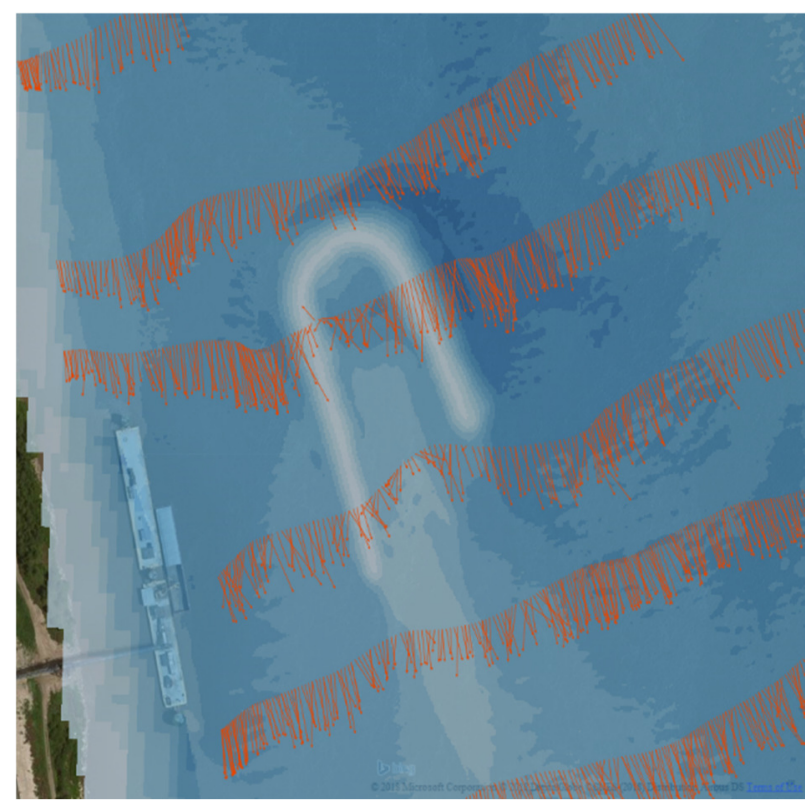

Figure 8: ADCP velocity measurements around a chevron at St. Louis Harbor (flow of $15300 \mathrm{~m}^{3} / \mathrm{s}$ ). The figure indicates that, once the chevron is fully submerged, there is no visible flow split or obstruction of the passing flow.

Slika 8: Meritve hitrosti ADCP okoli podkvastega usmerjevalnika toka v pristanišču St. Louis Harbor (pretok $15300 \mathrm{~m}^{3} / \mathrm{s}$ ). Slika kaže, da ni vidne razcepitve toka ali obstrukcije toka, ko je podkvasti usmerjevalnik toka potopljen.
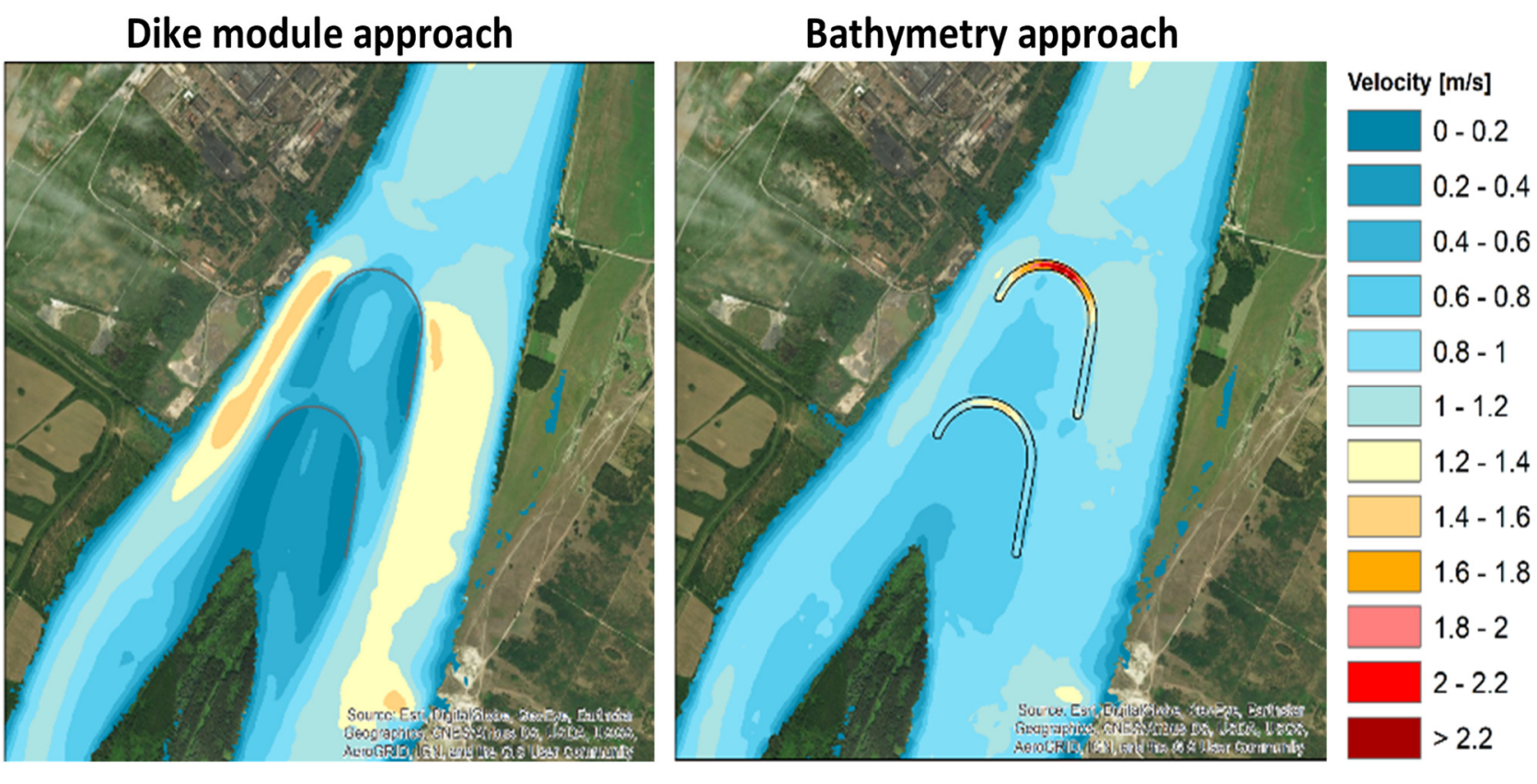

Figure 9: The dike module and bathymetry approach 2D model velocities (flow of $8000 \mathrm{~m}^{3} / \mathrm{s}$ ).

Slika 9: 2D modelne hitrosti za pristop z jezbičnim modulom in batimetrični pristop (pretok $8000 \mathrm{~m}^{3} / \mathrm{s}$ ). 
This is further highlighted in Figure 10, which shows the $2 \mathrm{D}$ model velocity vectors for the dike module and bathymetry approach. Figure 10 further indicates that dike module approach acts an obstruction to the passing flow, which led to a significant flow split at the structure. However, field observations and measurements clearly show that chevrons have a reduced effect on local flow

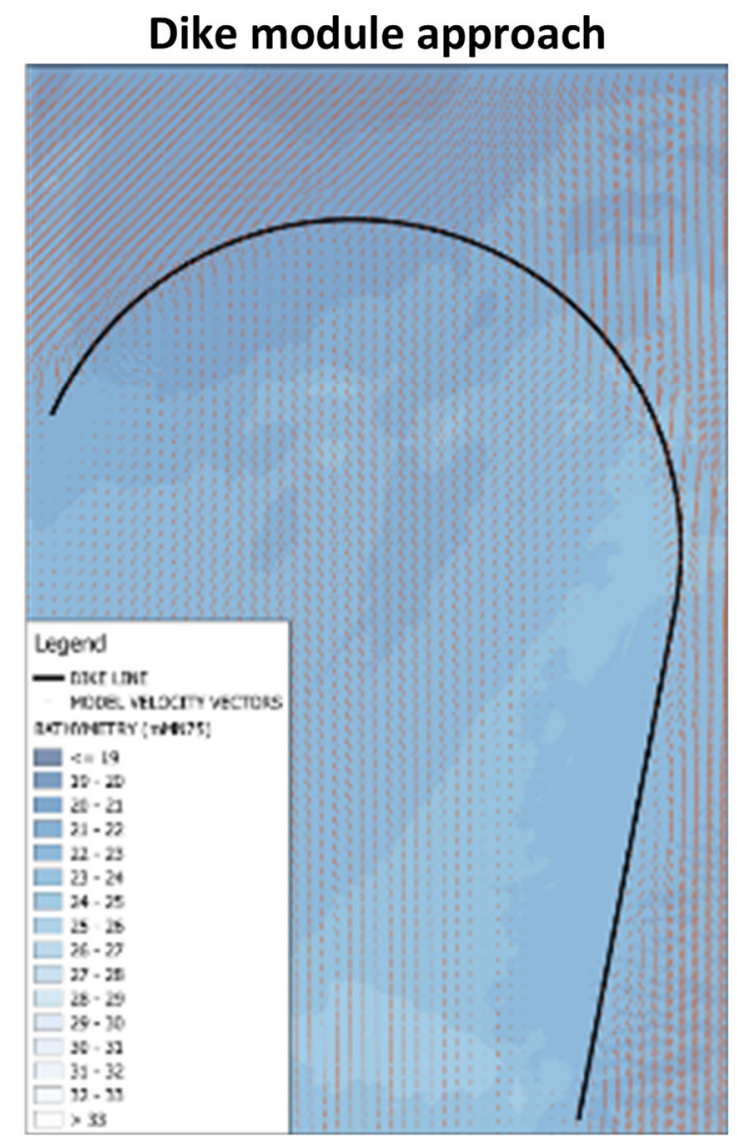

fields once they are fully submerged. On the other side, it can be again seen from Figure 10 that the bathymetry approach appears to result in a more realistic predicted flow field around a submerged chevron: the flow passes over the submerged structure without any significant disturbances or deflections.

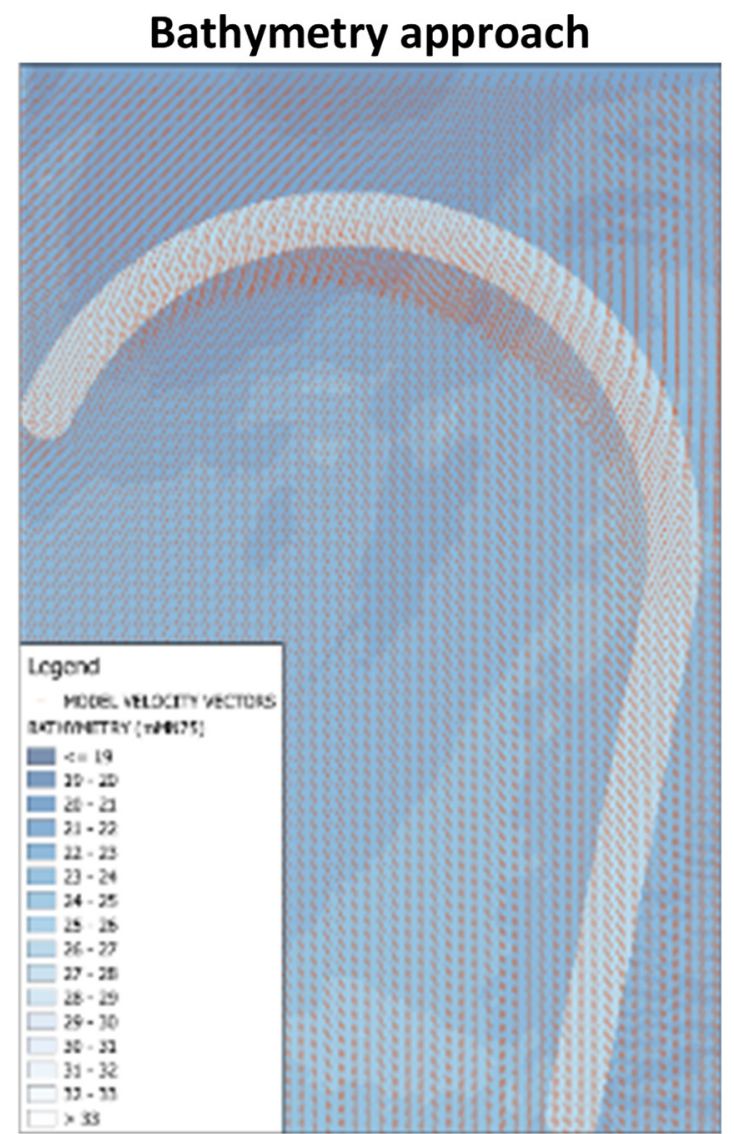

Figure 10: Dike module and bathymetry approach 2D model velocity vectors (flow of $8000 \mathrm{~m}^{3} / \mathrm{s}$ ).

Slika 10: $2 D$ modelni vektorji hitrosti za pristop z jezbičnim modulom in batimetrični pristop (pretok 8000 $\left.\mathrm{m}^{3} / \mathrm{s}\right)$.

\section{Discussion}

The comparison of model results with (i) published theoretical and empirical formulae for estimating discharge over submerged weir-type structures and (ii) field observations indicates:

- the dike module approach tends to underestimate the flow over the structure because:

- the component of flow over the structure parallel to the structure is not calculated; however, this should be considered as the parallel component of the flow physically occurs for submerged structures that are not aligned perpendicular to the main flow direction

- flow is calculated using Villemonte's original reduction method for submerged flow perpendicular to sharp-crested weirs: in order to apply this method to trapezoidal section submerged structures, for which the energy loss is substantially 
lower, a variation in the exponent of the submergence ratio according to depth of submergence is required (Wols et al., 2006), which cannot be implemented in the MIKE 21 Flow Model FM

- the bathymetry approach tends to compare favourably with:

- the general flow patterns measured at submerged structures in the field

- the published data and methods for submerged trapezoidal structures, such as Fritz and Hager (1998) and Ali and Uijttewaal (2014)

For the bathymetry approach, two-dimensional flow over the structure is calculated parallel and perpendicular to the structure, and results compare favourably with empirical methods. Energy loss due to flow contraction and expansion is not explicitly calculated, although it is possible to adjust the energy loss at the structures by locally adjusting the model roughness value. However, for submerged trapezoidal shaped structures, these losses are less significant than for sharp-crested structures, where the change flow depth is much more abrupt (Huthoff et al., 2013). Furthermore, the bathymetry method has been applied by other practitioners for representing submerged chevron and dike structures (Gessler et al., 2010; Remo et al., 2013), with these studies indicating that the model results tend to agree well with the field observations.

For the dike module approach, it is possible to vary (increase) the base weir discharge coefficient to obtain results that are more consistent with published data for part of the flow range. However, it is not possible to represent the empirical variation of submerged flow coefficients in relation to the structure's submergence. Although the freeflow weir discharge coefficient can be adjusted, it will not lead to an adequate representation of a submerged broad-crested structure's behaviour. For example, Huthoff et al. (2013) have computed a vertical velocity field in a three-dimensional (3D) numerical model for a submerged sharp-crested and trapezoidal section weir. They have shown that with a trapezoidal "stream-lined" structure, the zone of recirculating flow (and energy loss) immediately downstream from the structure is suppressed, resulting in less energy loss and a higher effective discharge coefficient.

This difference in behaviour can be seen in empirical relationships derived from experimental data for the considered types of structures, e.g. Villemonte's formula for sharp-crested weirs (as implemented in the MIKE 21 Flow Model FM) and the Ali and Uijttewaal (2014) relation for trapezoidal weirs, which is the general shape of river training structures. The Villemonte's equation predicts around $50 \%$ or less discharge for a given energy loss compared to the method proposed by Ali and Uijttewaal (2014), which indicates that the dike module approach is not the best solution for modelling of submerged detached or semidetached river training structures. Although the submerged discharge coefficient in the Villemonte's formula can be increased in MIKE 21 Flow Model FM by increasing the free-flow coefficient, a very large increase (100-200\%) is needed to provide similar behaviour at high submergence ratios. In turn, this results in significant overestimation of discharge at lower submergence ratios.

\section{Conclusions}

In this study, we have analysed two different approaches for 2D hydraulic modelling of submerged river training structures (i.e. dikes and chevrons) with MIKE 21 Flow Model FM: (i) by representing the geometry of the structures explicitly in the bathymetry of the river channel (i.e. bathymetry approach), and (ii) by utilising the dike sub-grid module, where the flow past a structure is calculated by employing an empirical discharge relationship (i.e. dike module approach). The model results have been compared to theoretical and empirical studies, as well as qualitatively compared to field observations and measurements taken for chevrons in the Mississippi River.

Four empirical and theoretical methods for estimating the energy loss at a cross-section of a submerged weir-type structure have been 
compared to results of model simulations of the flow over and around submerged dikes. The dike module approach results agree reasonably well with the empirical methods derived for submerged sharp-crested weirs or short-crested, rectangularshaped weirs. However, the model results tend to overpredict the energy loss as compared to methods derived for broader trapezoidal section submerged structures, such as typical river training structures. With this method, it is only possible to adjust the free-flow discharge coefficient, which does not fully take account of the behavioural differences between short-crested and trapezoidal weirs. The bathymetry approach results agree reasonably well with the empirical and theoretical methods derived for broader trapezoidal section submerged structures, but show less energy loss than methods derived for shorter crested rectangular weirs. With this method, the energy loss can be adjusted through varying the bed roughness coefficient, which can easily improve the model results.

Simulations of the flow over and around a submerged chevron using the dike module and bathymetry approach for the same flow conditions show quite different behaviour in terms of their two-dimensional flow patterns. The results for the dike module approach show areas of flow stagnation downstream from the structure and significant increases in the flow diverted around the structure. The field measurements of flow over a submerged chevron built in the Mississippi River indicate that flow tends to pass over the chevron with more limited obstruction of flow and less obvious stagnation zones. The results from simulations with the bathymetry approach show flow passing along the structure's crest and no significant stagnation downstream from the structure.

Based on the obtained results, the bathymetry approach is considered the more appropriate method for simulating predominantly submerged river training structures, which are detached or semi-detached and partially to fully aligned to the main flow direction. Nonetheless, representation of the behaviour of such structures in a twodimensional model (such as MIKE 21) is simplified regardless of the method adopted due to the complex flow regime at these types of submerged structures. These types of models should be used only for general assessment of potential river engineering solutions. For more detailed assessment of solution options, the sensitivity of the model-simulated outcomes to the uncertainty in modelling such structures must be considered, and alternative model types are recommended for a detailed design of the preferred solutions, such as 3D hydrodynamic models or physical model.

\section{Acknowledgements}

The author would like to thank Jon Remo for kindly providing the field measurements. The author would also like to thank Damian Debski for his assistance and valuable comments.

\section{References}

Ali, S. and Uijttewaal, W. (2014). Flow resistance of vegetated oblique weir-like obstacles during high water stages. Hydrology and Earth System Sciences, 18(1), 114. DOI: https://doi.org/10.5194/hess-18-1-2014

Azimi, A. H., Rajaratnam, N. and Zhu, D. Z. (2014). Submerged flows over rectangular weirs of finite crest length. Journal of irrigation and drainage Engineering, 140(5), $\quad 06014001$.

DOI: https://doi.org/10.1061/(ASCE)IR.1943-4774.0000728

Bagheri, S. and Heidarpour, M. (2010). Flow over rectangular sharp-crested weirs. Irrigation science, 28(2), 173. DOI: https://doi.org/10.1007/s00271-0090172-1

Borghei, S., Jalili, M. and Ghodsian, M. (1999). Discharge coefficient for sharp-crested side weir in subcritical flow. Journal of Hydraulic Engineering, 125(10), 1051-1056.

https://doi.org/10.1061/(ASCE)07339429(1999)125:10(1051)

Bos, M. (1989). Discharge measurement structures (3 ed.). Wageningen, the Netherlands: ILRI.

Chadwick, A., Morfett, J. and Borthwick, M. (2013). Hydraulics in civil and environmental engineering, CRC Press. Boca Raton, London, New York, 648 p.

Collas, F. P. L., Buijse, A. D., van den Heuvel, L., van Kessel, N., Schoor, M. M., Eerden, H. and Leuven, R. S. E. W. (2018). Longitudinal training dams mitigate 
effects of shipping on environmental conditions and fish density in the littoral zones of the river Rhine. Science of The Total Environment, 619-620, 1183-1193. DOI: https://doi.org/10.1016/j.scitotenv.2017.10.299

Davinroy, R. D. (1996). Design of blunt nosed chevrons in the Mississippi River for sediment management. Proceedings of the Sixth Federal Interagency Sedimentation Conference. Interagency Advisory Committee on Water Data Subcommittee on Sedimentation, Las Vegas, Nevada, 86.

DHI. (2017). MIKE 21 Flow Model FM, Hydrodynamic Module, User Guide. Hørsholm, Denmark.

Dyhouse, G. R. and Brauer, E. J. (2010). The Impact of Navigation Chevrons in St. Louis Harbor. Proceedings of the Watershed Management 2010: Innovations in Watershed Management under Land Use and Climate Change, Madison, Wisconsin, 258-264.

Fritz, H. M. and Hager, W. H. (1998). Hydraulics of embankment weirs. Journal of Hydraulic Engineering, 124(9), 963-971.

DOI:

https://doi.org/10.1061/(ASCE)0733-

9429(1998)124:9(963)

Gessler, D., Biedenharn, D., Watson, C., Nygaard, C. and Peters, M. (2010). Multi-dimensional modeling of the Cowlitz-Columbia confluence. Paper presented at the 2nd Joint Federal Interagency Conference, Las Vegas, Nevada.

Glas, M., Glock, K., Tritthart, M., Liedermann, M. and Habersack, H. (2018). Hydrodynamic and morphodynamic sensitivity of a river's main channel to groyne geometry. Journal of Hydraulic Research, 1-13. DOI: https://doi.org/10.1080/00221686.2017.1405369

Göğüş, M., Defne, Z. and Özkandemir, V. (2006). Broad-crested weirs with rectangular compound cross sections. Journal of irrigation and drainage Engineering, 132(3), 272-280. DOI: https://doi.org/10.1061/(ASCE)0733-

9437(2006)132:3(272)

Huthoff, F., Braneveld, H., Pinter, N., Remo, J., Eerden, H. and Paarlberg, A. (2013). Optimizing design of river training works using 3-dimensional flow simulations. Proceedings of the Smart Rivers Conference 2013, Liege (BE), Maastricht (NL),

Johnson, M. C. (2000). Discharge coefficient analysis for flat-topped and sharp-crested weirs. Irrigation science, $19(3), \quad$ 133-137. DOI: https://doi.org/10.1007/s002719900009

Kumar, S., Ahmad, Z. and Mansoor, T. (2011). A new approach to improve the discharging capacity of sharpcrested triangular plan form weirs. Flow Measurement and Instrumentation, 22(3), 175-180. DOI: https://doi.org/10.1016/j.flowmeasinst.2011.01.006

Le, T. B., Crosato, A. and Uijttewaal, W. S. J. (2018). Long-term morphological developments of river channels separated by a longitudinal training wall. Advances in Water Resources, 113, 73-85. DOI: https://doi.org/10.1016/j.advwatres.2018.01.007

Liedermann, M., Gmeiner, P., Kreisler, A., Tritthart, M. and Habersack, H. (2018). Insights into bedload transport processes of a large regulated gravel-bed river. Earth Surface Processes and Landforms, 43(2), 514523. DOI: $\underline{\text { https://doi.org/10.1002/esp.4253 }}$

Luo, M. and Criss, R. E. (2018). Increasing Stage Variability of the Mississippi River. Journal of Hydrologic Engineering, 23(8), 05018016. DOI: https://doi.org/10.1061/(ASCE)HE.1943-5584.0001678

Maddock, I. (1999). The importance of physical habitat assessment for evaluating river health. Freshwater biology, 41(2), 373-391. DOI: https://doi.org/10.1046/j.1365-2427.1999.00437.x

Papanicolaou, A. N. and Elhakeem, M. (2006). Hydraulic performance of shallow water habitat in the Missouri River for ecological studies. Proceedings of the 7th International Conference on HydroScience and Engineering, Philadlephia, USA, 8.

Pinter, N., Dierauer, J. and Remo, J. W. (2012). Floodloss modelling for assessing impacts of flood-frequency adjustment, Middle Mississippi River, USA. Hydrological Processes, 26(19), 2997-3002. DOI: https://doi.org/10.1002/hyp.9321

Ramamurthy, A. S., Tim, U. S. and Rao, M. (1987). Flow over sharp-crested plate weirs. Journal of irrigation and drainage Engineering, 113(2), 163-172. DOI: $\quad$ https://doi.org/10.1061/(ASCE)07339437(1987)113:2(163)

Remo, J. W. F., Khanal, A. and Pinter, N. (2013). Assessment of chevron dikes for the enhancement of physical-aquatic habitat within the Middle Mississippi River, USA. Journal of hydrology, 501, 146-162. DOI: https://doi.org/10.1016/j.jhydrol.2013.07.007

Singh, P. and Sharma, N. (2014). Investigation of impacts of Chevron as a river training measure on river hydraulics. Proceedings of the International Conference on Agricultural, Environmental and Biological Sciences (AEBS-2014), Patong Beach-Phuket, Thailand, 36-41.

Sobotka, M. and Phelps, Q. (2017). A Comparison of Main and Side Channel Physical and Water Quality Metrics and Habitat Complexity in the Middle Mississippi River. River Research and Applications, 33(6), 879-888. DOI: https://doi.org/10.1002/rra.3061 
Theiling, C. H. (1995). Habitat rehabilitation on the upper Mississippi River. Regulated Rivers: Research \& Management, $\quad 11(2), \quad$ 227-238. DOI: https://doi.org/10.1002/rrr.3450110212

US Army Corps of Engineers. (2012). Chapter 7: River training structures and secondary channel modifications, Upper Mississippi River Restoration Environmental Management Program Environmental Design Handbook (pp. 76). Rock Island, Illinois: US Army Corps of Engineers.

van Vuren, S., Paarlberg, A. and Havinga, H. (2015). The aftermath of "Room for the River" and restoration works: Coping with excessive maintenance dredging. Journal of Hydro-environment Research, 9(2), 172-186. DOI: https://doi.org/10.1016/j.jher.2015.02.001

Villemonte, J. R. (1947). Submerged weir discharge studies. Engineering News-Record, 139(26), 54-56.

Wols, B., Uijttewaal, W. S., Labeur, R.-J. and Stelling, G. (2006). Rapidly varying flow over oblique weirs. Proceedings of the Proceedings of the 7th Int. Conf. On Hydroscience and Engineering (ICHE-2006), 1-13.
Wu, S. and Rajaratnam, N. (1996). Submerged flow regimes of rectangular sharp-crested weirs. Journal of Hydraulic Engineering, 122(7), 412-414. DOI: https://doi.org/10.1061/(ASCE)07339429(1996)122:7(412)

Zuijderwijk, M., Muskatarovic, J., Mitrovic, I., Tjerry, S. and Zanetti, R. (2013). Environmental friendly solutions to improve the navigation fairway of the Danube in Serbia. Proceedings of the Smart Rivers Conference 2013, Liege (BE), Maastricht (NL), 9. 